\title{
Original Paper \\ Flood and fire affect the soil seed bank of riparian forest in the Pantanal wetland
}

\author{
Thiago da Costa Kohagura ${ }^{1}$, Evaldo Benedito de Souza ${ }^{2,4,5}$, Francielli Bao ${ }^{3}$, Fernando Alves Ferreira ${ }^{1} \&$ Arnildo Pott ${ }^{1}$
}

\begin{abstract}
Flood and fire can harm plants but they can have survival strategies, such as the seed bank. We aimed to determine the influence of fire and flood on the richness, abundance and diversity of the seed bank. Sampling was carried out in October/2013, year of prolonged drought, and October/2014, year of a heavy flood, in ten areas along the Paraguay River. The areas were selected in satellite images, five with old burn (2010, three years before sampling) and five with recent burn (2013, three months before sampling). In each area, we marked a $20 \mathrm{~m}$ long transect with ten $20 \times 20 \mathrm{~cm}$ quadrats where we collected $5 \mathrm{~cm}$ deep topsoil samples, five with and five without litter. Seed bank richness and abundance were determined by seedling emergence. Old burn areas presented greater abundance than recent burn. The drier year presented greater abundance, richness and diversity than flood year. Removal of litter reduced the richness only in the wetter year. There was no difference in richness in the drier year. The removal of the litter did not affect the abundance and diversity. Interaction between fire and flood did not affect richness, abundance and diversity of the seed bank.

Key words: Diaspores; Fabaceae; floodable forest; neotropical wetland; plant ecology.

\section{Resumo}

Espécies vegetais sujeitas a Inundação e fogo podem manifestar estratégias de sobrevivência como o banco de sementes do solo. Pretendemos determinar a influência de fogo e inundação na riqueza, abundância e diversidade do banco de sementes. Realizamos amostragens em um ano mais seco (outubro/2013) e em um de maior inundação (outubro/2014), em dez áreas ao longo do rio Paraguai. Selecionamos 5 áreas com históricos de fogo antigo (2010, 4 anos antes da amostragem) e 5 recente (2013, 1 ano antes da amostragem). Nas áreas, marcamos transectos de 20 $\mathrm{m}$, nos quais coletamos 10 amostras de solo $(20 \times 20 \times 5 \mathrm{~cm})$, cinco com e cinco sem serrapilheira. Composição e abundância do banco de sementes foram estimadas por meio de emergência de plântulas. Áreas de fogo antigo apresentaram maior abundância que áreas de fogo recente. $\mathrm{O}$ ano de seca apresentou maiores abundância e riqueza do que o de inundação. A remoção da serrapilheira reduziu a riqueza no ano de inundação. Não houve diferença em riqueza no ano seco. A abundância nas amostras com e sem serrapilheira foram similares. A interação entre fogo e inundação não afetou a abundancia, riqueza e diversidade do banco de sementes.
\end{abstract}

Palavras-chave: diásporos; Fabaceae; floresta inundável; àreas úmidas; ecologia vegetal.

\section{Introduction}

The soil seed bank is a strategy to ensure the vegetation regeneration after a disturbance, or seasonal events such as fire (Santana et al.
2010) and flood (Hölzel \& Otte 2004). Annual and pluriannual fluctuations of floods determine plant recruitment and influence dispersal and the distribution of seeds in the soil (Brock \& Rogers

\footnotetext{
${ }^{1}$ Universidade Federal de Mato Grosso do Sul (UFMS), Inst. Biociências, Prog. Pós-graduação em Biologia Vegetal, Av. Costa e Silva s/n, Bairro Universitário, 79070-900, Campo Grande, MS, Brazil.

${ }^{2}$ Universidade Federal de Mato Grosso do Sul (UFMS), Instituto de Biociências, Prog. Pós-graduação em Ecologia e Conservação, Av. Costa e Silva s/n, Bairro Universitário, 79070-900, Campo Grande, MS, Brazil.

${ }^{3}$ Universidade Estadual Paulista (UNESP), Instituto de Biociências, Campus de Rio Claro, 13506-900, Rio Claro, SP, Brazil.

${ }^{4}$ ORCID: <https://orcid.org/0000-0003-4218-2749>

${ }^{5}$ Author for correspondence: bs.evaldo@gmail.com
} 
1998). Water dispersed seeds come mixed with plant debris, in great part from aquatic plants that germinate during floods (Bao et al. 2017). This accumulated organic debris, associated with aquatic macrophyte dieback, can capture and trap dispersing seeds (Ruprecht \& Szabó 2012), potentially increasing local seed bank abundance and richness (Bao et al. 2018). Flood also acts as a trigger for the seedling emergence of annual species, rapidly withdrawing seeds from the bank and reducing its richness and abundance (Souza et al. 2016). It is expected that in years of lesser flood and in flood-free areas, germination and seedling emergence would be lower, so maintaining higher richness and abundance of seeds in the soil (Brock et al. 2003). However, there are few pieces of evidence of differences of seed bank richness and abundance between dry and flooded years.

Fire is another factor that influences the structure and diversity of the vegetation (Oliveira et al. 2014). The buildup of biomass, either from aquatic plants at flood or from terrestrial plants grown post-flood, is fuel for a wildfire. Depending on intensity, fire can act overcoming the seed dormancy (Santana et al. 2013) and removal of plant cover (Moreira \& Pausas 2012), increasing light and so promoting seedling recruitment from the seed bank (Keeley et al. 2011). If intervals between the burning of aerial vegetation exceed the longevity of seeds in the soil, they can lose viability before fire generated gaps could favour germination (Keith \& Bradstock 1994). Longer seed longevity causes lower fluctuation of the seed bank than short-lived species (Brock \& Rogers 1998). Thus, the exclusion of fire for a long period can increase the richness and abundance of the seed bank up to some degree, due to lack of gaps for germination.

In the Pantanal, fire and flood are considered extreme seasonal events which temporarily (intraannual and interannual) and spatially modify the structure and species richness of the vegetation. These two factors can interact in determining the vegetation composition. Fire events can be restricted when the flood is more intense, allowing more flood tolerant and less fire-tolerant species to become established. To the contrary, when flood intensity is lower, the occurrence of fire can reach high proportions, eliminating less tolerant species (Arruda et al. 2016). For that reason, our study had the objectives to assess the abundance, richness and diversity of the riparian forest seed bank in a stretch of the Paraguay River, Pantanal wetland, Corumbá, Mato Grosso do Sul, and to verify if fire and flood can interfere in the abundance, species richness and diversity of the soil seed bank. Therefore, we tried to answer the following questions: 1) Do inundation and fire history influence abundance, richness and diversity of the soil seed bank? 2) Are there differences in abundance, richness and diversity between soil with litter and without litter?

\section{Material and methods}

\section{Study area}

The study was carried out on both margins of a stretch of the riparian forest of the Paraguay River, between the coordinates $19^{\circ} 31^{\prime} 23.97^{\prime \prime} \mathrm{S}$ 57'6'1.9'W and 1941'38'S 56 59'56.4'W (Fig.1), in the municipality of Corumbá, Mato Grosso do Sul, Brazil. This floodplain has sandy-loamy to clayey Gleysol, eutrophic or dystrophic and aluminic, characteristic of lowlands under constant or periodical floods (Fernandes et al. 2007).

According to Köppen's classification, the climate of Corumbá is Awa, i.e., tropical megathermic (mean temperature of the coolest month $>18^{\circ} \mathrm{C}$ ), seasonal, with dry winter and rainy summer, with mean annual rainfall of $1100 \mathrm{~mm}$, average annual temperature of $21-31{ }^{\circ} \mathrm{C}$, and mean annual relative humidity of $76.8 \%$ (Soriano 1997). Paradoxically, local flood time is not related to the local rainy season, but with rains on the headwaters of the Upper Paraguay Basin, with three months lag because the waters flow slowly downstream, since the Pantanal is very flat, with an N-S declivity of only $2.5 \mathrm{~cm} / \mathrm{km}$ (Brasil 1979). Thereby, flooding on the plain occurs in the dry season, so extending the period of soil moisture, allowing Amazonian trees to occur in the riparian forest (Damasceno-Junior et al. 2004; Arruda et al. 2016). However, in drier years the river does not overflow, when its level stays below $4 \mathrm{~m}$ (daily recorded by the Navy fluviometric station at Ladário, close to the study area), and fire may occur due to the buildup of dry organic matter in the adjacent grasslands (Hamilton et al. 1996).

\section{Data collection}

To choose the sampling areas we utilized Landsat 5 images obtained from the Instituto Nacional de Pesquisas Espaciais (INPE). We consulted the flood records of the last five years, to detect when the Paraguay River was low and thus fire could reach the riparian forest, the chosen years being 2010 and 2013. Next, we inspected the satellite images for signs (black) of burned areas in the driest months of those years. We marked and 

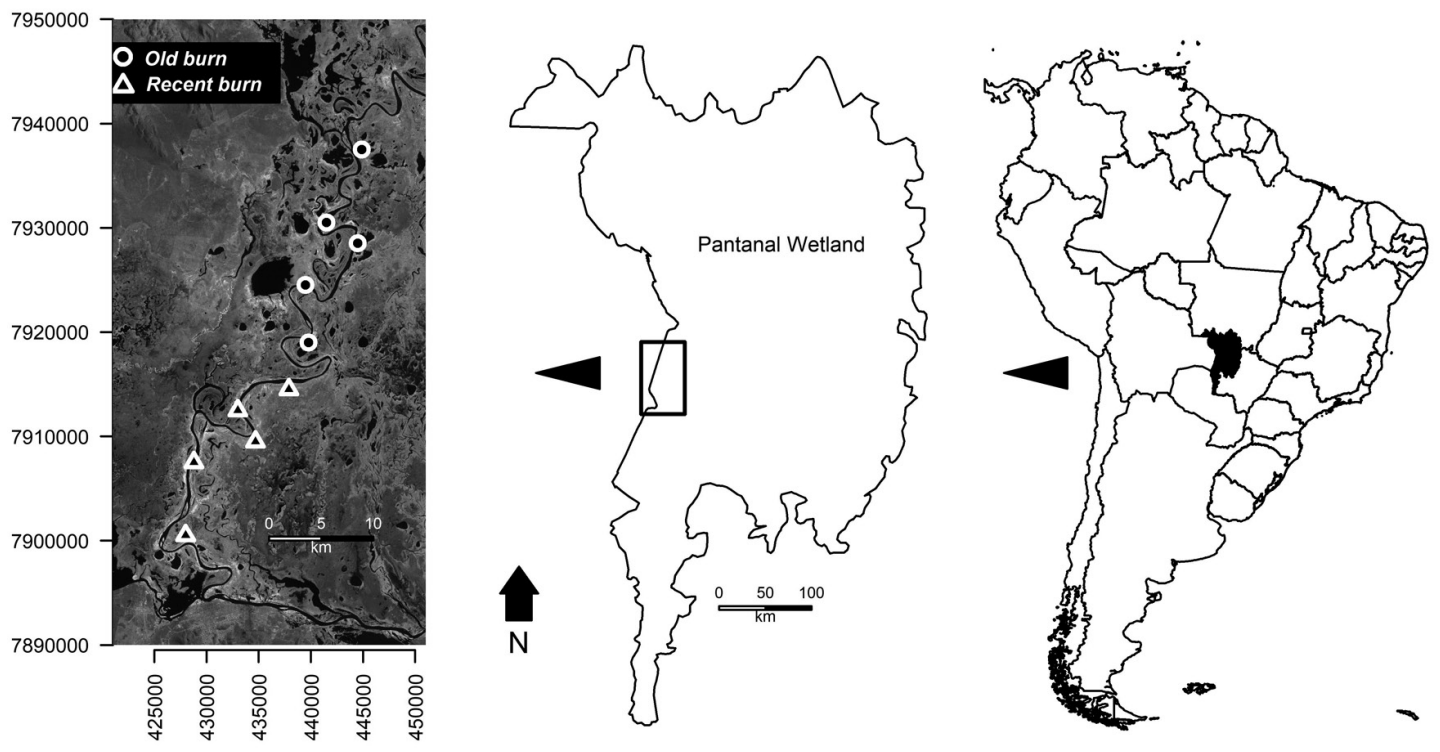

Figure 1 - Location of the studied region showing areas of recent and old burn in riparian forest of the Paraguay River, Pantanal wetland, Brazil.

georeferenced five areas of old burn (2010, three years before sampling) and five of recent burn (2013, three months before sampling), totalling 10 sampling areas along a stretch of the Paraguay River (Fig. 1).

In each sampling area we marked a $20 \mathrm{~m}$ long transect and at $5 \mathrm{~m}$ intervals we took two paired soil samples (five including litter and five without it), i.e., 10 samples per transect, adding to 50 samples of old burn and 50 of the recent burn, total of 100 . The sample was a $20 \times 20 \mathrm{~cm}$ slice of $5 \mathrm{~cm}$ topsoil. The samplings were performed in two hydrologic conditions, the first in October 2013 (year of prolonged drought) and the second in October 2014 (year of a heavy flood). The second fieldwork had been planned for May 2014, but the area was flooded until October when it became possible to collect soil.

The collected soil samples were kept in labelled plastic bags and taken to the greenhouse at the Universidade Federal de Mato Grosso do Sul. We spread the soil over a $2 \mathrm{~cm}$ layer of washed and seed free sand into labelled plastic trays of $6.5 \times$ $19.5 \times 31 \mathrm{~cm}$, perforated for drainage, randomly placed and weekly rotated on benches in a screened greenhouse ( $50 \%$ shade), under room temperature and irrigated twice a day by automatic sprinklers. The species composition and abundance of the soil seed bank were estimated by the seedling emergence method, whereby germinated seeds were counted, identified and removed to avoid competition with new seedlings (Boedeltje et al. 2002). We recorded the number of emerged seedlings in the trays at seven-day intervals. For the year of drought we made 15 counts and for the wetter year, 13. Emerged seedlings were identified and counted per species, then removed. Species identification was occasionally only possible during flowering. Some yet unidentified species were transplanted to pots for later identification and then added to the records. For identification, we used field guides of local flora (e.g., Pott \& Pott 1994, 2000) and experience of the authors.

\section{Analysis of data}

To test the effect of hydrologic condition and of fire history we utilized generalized linear models (GLM), with the function $\operatorname{glm}()$ in the R statistical programming language, version 3.4.0 (R Core Team 2017). We chose GLMs because our data did not fit into a normal distribution. Species richness and abundance data fit a Poisson distribution, but due to the overdispersion of data, we applied a QuasiGLM model to correct the standard errors (Zuur et al. 2009). We calculated Shannon diversity for each sample using the diversity() function of the vegan package (Oksanen 2017). We tested the effect of fire and flood, on the Shannon diversity with GLM with a Gaussian distribution and log link function. The influence of flood (year of drought and year 
of heavy flood) and fire condition (old and recent burn) on richness abundance and Shannon diversity was analyzed in a bifactorial model with interaction between fire and flood conditions. The influence of litter on richness, abundance and Shannon diversity was analyzed separately for each flood condition.

\section{Results}

In the soil seed bank in a stretch of the riparian forest of the Paraguay River, we recorded 7195 emerged seedlings, distributed in 24 families, 53 genera and 61 species (Tab. 1). The families with highest species richness were Fabaceae (eight species), Cyperaceae and Poaceae (seven species), Euphorbiaceae and Onagraceae (five species), adding to $53 \%$ of the identified species. The families Asteraceae and Malvaceae (three species), Convolvulaceae, Lamiaceae, Polygonaceae and Plantaginaceae (two species) represented $7.3 \%$ of species. The others had a single species each, however, Urticaceae stood out for the high abundance of Cecropia pachystachya Trécul.
The most abundant genera were Cecropia, Cyperus, Ludwigia, Hymenachne, Borreria and Randia, expressing $68.5 \%$ of the total of species recorded in the seed bank, and the main species were Cyperus haspan L. (11\%), Cecropia pachystachya (10\%), Borreria quadrifaria E.L. Cabral (10\%), Ludwigia decurrens Walter (9.5\%) and Randia armata (Sw.) DC. (9\%). Herbs were strongly dominant in both years, as we recorded 3,113 seedlings in 2013 (dry), and 3,029 in 2014 (flood), a total of 6,142 , corresponding to $86 \%$ of the seedlings identified in the seed bank.

Other growth habits were also recorded, such as vines, shrubs and subshrubs. We recorded eight liana species, with 143 seedlings emerged from the seed bank, the most abundant being Canavalia mattogrossensis (Barb.Rodr.) Malme (40 seedlings), Rhynchosia minima (L.) DC. (37) and Mikania micrantha Kunth (31). Shrubs were represented by eight species and a total of 771 seedlings, corresponding to $11 \%$ of all seedlings, the most abundant species being $R$. armata (684)

Table 1 - List of species and their total abundances (TA) and habits $(\mathrm{H})$ present in the soil seed bank of areas with different fire histories (OB - old burn and RB - recent burn), in presence (P) and absence (A) of litter in dry and flood years, in riparian forest of the Paraguay River, Pantanal wetland, Corumbá, Mato Grosso do Sul, Brazil.

\begin{tabular}{|c|c|c|c|c|c|c|c|c|c|c|}
\hline \multirow{3}{*}{ Family/Species } & \multirow[b]{3}{*}{ TA } & \multirow[b]{3}{*}{$\mathrm{H}$} & \multicolumn{4}{|c|}{ Dry year } & \multicolumn{4}{|c|}{ Flood year } \\
\hline & & & \multicolumn{2}{|c|}{ RB } & \multicolumn{2}{|c|}{ OB } & \multicolumn{2}{|c|}{ RB } & \multicolumn{2}{|c|}{ OB } \\
\hline & & & $\mathrm{P}$ & $\mathrm{A}$ & $\mathrm{P}$ & A & $\mathrm{P}$ & A & $\mathrm{P}$ & A \\
\hline \multicolumn{11}{|l|}{ Amaranthaceae } \\
\hline Pfaffia glomerata (Spreng.) Pedersen & 1 & Herb & 0 & 0 & 1 & 0 & 0 & 0 & 0 & 0 \\
\hline \multicolumn{11}{|l|}{ Asteraceae } \\
\hline Aspilia latissima Malme & 12 & Herb & 0 & 0 & 6 & 3 & 0 & 0 & 3 & 0 \\
\hline Melanthera latifolia (Gardn.) Cabrera & 36 & Herb & 6 & 2 & 0 & 2 & 10 & 8 & 0 & 8 \\
\hline Mikania micrantha Kunth & 31 & Liana & 3 & 5 & 10 & 2 & 6 & 3 & 1 & 1 \\
\hline \multicolumn{11}{|l|}{ Boraginaceae } \\
\hline Euploca procumbens (Mill.) Diane \& Hilger & 17 & Herb & 0 & 0 & 3 & 10 & 0 & 0 & 2 & 2 \\
\hline Heliotropium indicum $\mathrm{L}$. & 10 & Herb & 0 & 0 & 2 & 2 & 2 & 0 & 2 & 2 \\
\hline \multicolumn{11}{|l|}{ Convolvulaceae } \\
\hline Ipomoea chiliantha Hallier $\mathrm{f}$. & 7 & Liana & 0 & 0 & 4 & 0 & 0 & 0 & 3 & 0 \\
\hline Ipomoea tenera Meissn. & 8 & Liana & 3 & 3 & 0 & 0 & 1 & 1 & 0 & 0 \\
\hline \multicolumn{11}{|l|}{ Cucurbitaceae } \\
\hline Cyclanthera hystrix (Gillies) Arn. & 12 & Liana & 0 & 3 & 3 & 3 & 0 & 2 & 0 & 1 \\
\hline \multicolumn{11}{|l|}{ Cyperaceae } \\
\hline Cyperus haspan $\mathrm{L}$. & 769 & Herb & 89 & 51 & 119 & 135 & 350 & 10 & 10 & 5 \\
\hline Cyperus surinamensis Rottb. & 366 & Herb & 83 & 51 & 71 & 102 & 10 & 20 & 19 & 10 \\
\hline
\end{tabular}




\begin{tabular}{|c|c|c|c|c|c|c|c|c|c|c|}
\hline \multirow{3}{*}{ Family/Species } & \multirow[b]{3}{*}{ TA } & & \multicolumn{4}{|c|}{ Dry year } & \multicolumn{4}{|c|}{ Flood year } \\
\hline & & & \multicolumn{2}{|c|}{ RB } & \multicolumn{2}{|c|}{ OB } & \multicolumn{2}{|c|}{ RB } & \multicolumn{2}{|c|}{ OB } \\
\hline & & $\mathrm{H}$ & $\mathrm{P}$ & A & $\mathrm{P}$ & A & $\mathrm{P}$ & A & $\mathrm{P}$ & A \\
\hline Eleocharis minima Kunth & 13 & Herb & 0 & 7 & 0 & 0 & 6 & 0 & 0 & 0 \\
\hline Eleocharis plicarhachis (Griseb.) Svens. & 9 & Herb & 0 & 6 & 0 & 0 & 0 & 0 & 3 & 0 \\
\hline Fimbristylis dichotoma (L.) Vahl & 21 & Herb & 0 & 2 & 0 & 5 & 0 & 7 & 7 & 0 \\
\hline Lipocarpha micrantha (Vahl) G.C. Tucher & 44 & Herb & 0 & 0 & 0 & 0 & 10 & 10 & 12 & 12 \\
\hline Rhynchospora corymbosa (L.) Britton & 5 & Herb & 1 & 1 & 0 & 0 & 3 & 0 & 0 & 0 \\
\hline \multicolumn{11}{|l|}{ Euphorbiaceae } \\
\hline Astraea lobata (L.) Klotzsch & 23 & Herb & 5 & 4 & 5 & 3 & 3 & 1 & 1 & 1 \\
\hline Caperonia castaneifolia (L.) A. St.-Hil. & 2 & Herb & 1 & 0 & 0 & 0 & 0 & 0 & 1 & 0 \\
\hline Croton trinitatis Millsp. & 34 & Herb & 8 & 3 & 8 & 2 & 5 & 5 & 1 & 2 \\
\hline Dalechampia scandens $\mathrm{L}$. & 4 & Liana & 3 & 0 & 0 & 0 & 0 & 1 & 0 & 0 \\
\hline Euphorbia thymifolia $\mathrm{L}$. & 8 & Herb & 0 & 0 & 0 & 0 & 0 & 5 & 3 & 0 \\
\hline \multicolumn{11}{|l|}{ Fabaceae } \\
\hline Aeschynomene sensitiva $\mathrm{Sw}$. & 2 & Herb & 1 & 0 & 0 & 0 & 1 & 0 & 0 & 0 \\
\hline Bauhinia bauhinioides (Mart.) Macbr. & 1 & Shrub & 0 & 0 & 0 & 1 & 0 & 0 & 0 & 0 \\
\hline Canavalia mattogrossensis (Rodr.) Malme & 4 & Liana & 1 & 0 & 0 & 0 & 1 & 1 & 1 & 0 \\
\hline Mimosa adenocarpa Benth. & 28 & Shrub & 3 & 2 & 2 & 11 & 3 & 3 & 2 & 2 \\
\hline Neptunia plena (L.) Benth. & 26 & Herb & 3 & 2 & 2 & 15 & 1 & 1 & 1 & 1 \\
\hline Rhynchosia minima (L.) DC. & 37 & Liana & 15 & 0 & 12 & 10 & 0 & 0 & 0 & 0 \\
\hline Sesbania exasperata Kunth & 5 & Shrub & 5 & 0 & 0 & 0 & 0 & 0 & 0 & 0 \\
\hline Vigna longifolia (Benth.) Verdc. & 7 & Herb & 2 & 0 & 0 & 0 & 5 & 0 & 0 & 0 \\
\hline \multicolumn{11}{|l|}{ Lamiaceae } \\
\hline Hyptis brevipes Poit. & 136 & Herb & 10 & 10 & 10 & 3 & 50 & 50 & 0 & 3 \\
\hline Hyptis suaveolens(L.) Poit. & 26 & Herb & 0 & 0 & 5 & 5 & 0 & 0 & 8 & 8 \\
\hline \multicolumn{11}{|l|}{ Lythraceae } \\
\hline Rotala ramosior (L.) Koehne & 69 & Herb & 0 & 0 & 30 & 0 & 0 & 0 & 39 & 0 \\
\hline \multicolumn{11}{|l|}{ Malvaceae } \\
\hline Byttneria divaricata Benth. & 21 & Shrub & 5 & 0 & 0 & 6 & 6 & 0 & 0 & 4 \\
\hline Melochia arenosa Benth. & 24 & Subshrub & 2 & 2 & 2 & 2 & 2 & 0 & 10 & 4 \\
\hline Pavonia laeteviren R.E. Fr. & 22 & Shrub & 0 & 0 & 12 & 3 & 0 & 0 & 0 & 7 \\
\hline \multicolumn{11}{|l|}{ Melastomataceae } \\
\hline Rhynchanthera novemnervia DC. & 3 & Herb & 0 & 0 & 1 & 0 & 0 & 0 & 1 & 1 \\
\hline \multicolumn{11}{|l|}{ Onagraceae } \\
\hline Ludwigia decurrens Walter & 729 & Herb & 31 & 27 & 408 & 100 & 41 & 41 & 39 & 42 \\
\hline $\begin{array}{l}\text { Ludwigia grandiflora (Michx.) Greuter \& } \\
\text { Burdet }\end{array}$ & 162 & Herb & 20 & 20 & 20 & 20 & 10 & 30 & 20 & 22 \\
\hline Ludwigia leptocarpa (Nutt.) H. Hara & 88 & Herb & 7 & 3 & 6 & 10 & 1 & 0 & 31 & 30 \\
\hline Ludwigia octovalvis (Jacq.) P.H. Raven & 108 & Herb & 1 & 30 & 12 & 30 & 33 & 2 & 2 & 1 \\
\hline Ludwigia tomentosa (Cambess.) H. Hara & 7 & Shrub & 1 & 0 & 5 & 1 & 0 & 0 & 0 & 0 \\
\hline \multicolumn{11}{|l|}{ Plantaginaceae } \\
\hline Bacopa australis V.C. Souza & 22 & Herb & 22 & 0 & 0 & 0 & 0 & 0 & 0 & 0 \\
\hline
\end{tabular}




\begin{tabular}{|c|c|c|c|c|c|c|c|c|c|c|}
\hline \multirow{3}{*}{ Family/Species } & \multirow[b]{3}{*}{ TA } & & \multicolumn{4}{|c|}{ Dry year } & \multicolumn{4}{|c|}{ Flood year } \\
\hline & & & \multicolumn{2}{|c|}{ RB } & \multicolumn{2}{|c|}{ OB } & \multicolumn{2}{|c|}{ RB } & \multicolumn{2}{|c|}{ OB } \\
\hline & & $\mathrm{H}$ & $\mathrm{P}$ & A & $\mathrm{P}$ & A & $\mathrm{P}$ & A & $\mathrm{P}$ & A \\
\hline Scoparia dulcis L. & 14 & Herb & 5 & 0 & 4 & 4 & 0 & 0 & 0 & 1 \\
\hline \multicolumn{11}{|l|}{ Poaceae } \\
\hline Digitaria bicornis (L.) Roem. \& Schult. & 148 & Herb & 0 & 100 & 0 & 20 & 0 & 0 & 28 & 0 \\
\hline Eragrostis rufescens Schrad. ex Schult. & 139 & Herb & 20 & 27 & 38 & 37 & 0 & 10 & 3 & 4 \\
\hline Hymenachne amplexicaulis Rudge & 515 & Herb & 100 & 48 & 41 & 39 & 50 & 185 & 30 & 22 \\
\hline Panicum dichotomiflorum Michx. & 68 & Herb & 0 & 0 & 20 & 18 & 0 & 0 & 30 & 0 \\
\hline Paspalum repens Berg. & 44 & Herb & 5 & 5 & 5 & 5 & 10 & 15 & 5 & 4 \\
\hline Setaria parviflora (Poir.) Kerguelen & 3 & Herb & 1 & 1 & 0 & 0 & 1 & 0 & 0 & 0 \\
\hline Steinchisma laxum (Sw.) Zuloaga & 341 & Herb & 50 & 40 & 50 & 40 & 20 & 50 & 50 & 41 \\
\hline \multicolumn{11}{|l|}{ Polygonaceae } \\
\hline Polygonum ferrugineum Wedd. & 30 & Herb & 5 & 5 & 5 & 5 & 3 & 2 & 3 & 2 \\
\hline Triplaris americana $\mathrm{L}$. & 3 & Tree & 3 & 0 & 0 & 0 & 0 & 0 & 0 & 0 \\
\hline \multicolumn{11}{|l|}{ Phyllanthaceae } \\
\hline $\begin{array}{l}\text { Phyllanthus amarus Schum. \& Thon. } \\
\text { Pteridaceae }\end{array}$ & 40 & Herb & 20 & 5 & 4 & 4 & 1 & 1 & 3 & 3 \\
\hline $\begin{array}{l}\text { Ceratopteris pteridoides (Hook.) Hieron. } \\
\text { Rubiaceae }\end{array}$ & 568 & Herb & 0 & 100 & 100 & 0 & 230 & 120 & 18 & 0 \\
\hline Borreria quadrifaria Cabral & 760 & Herb & 142 & 100 & 100 & 215 & 85 & 63 & 35 & 20 \\
\hline Randia armata (Sw.) DC. & 684 & Shrub & 200 & 150 & 0 & 75 & 75 & 75 & 0 & 109 \\
\hline Solanaceae & & & & & & & & & & \\
\hline $\begin{array}{l}\text { Solanum nigrescens M.Martens \& Galeotti } \\
\text { Sphenocleaceae }\end{array}$ & 3 & Herb & 1 & 0 & 0 & 0 & 1 & 1 & 0 & 0 \\
\hline $\begin{array}{l}\text { Sphenoclea zeylanica Gaertn. } \\
\text { Urticaceae }\end{array}$ & 2 & Herb & 0 & 0 & 2 & 0 & 0 & 0 & 0 & 0 \\
\hline $\begin{array}{l}\text { Cecropia pachystachya Trécul. } \\
\text { Verbenaceae }\end{array}$ & 766 & Tree & 193 & 219 & 143 & 108 & 50 & 20 & 30 & 3 \\
\hline $\begin{array}{l}\text { Lippia alba (Mill.) N.E. Br. ex Britton \& P. } \\
\text { Wilson } \\
\text { Vitaceae }\end{array}$ & 3 & Shrub & 1 & 1 & 0 & 0 & 0 & 1 & 0 & 0 \\
\hline Cissus spinosa Cambess. & 4 & Liana & 0 & 0 & 1 & 0 & 0 & 0 & 2 & 1 \\
\hline
\end{tabular}

and we recorded only a single subshrub, Melochia arenosa (24). All above-cited species were found either in areas of old or recent burn.

\section{Influence of post-fire periods} and hydrological conditions

There was no interaction between the factors fire (old and recent burn) and hydrologic condition (year of drought and year of the flood). Nonetheless, separately either factor influenced the abundance and richness of the seed bank. Regarding fire history, the old burn presented greater species richness $(\mathrm{t}=3.147, \mathrm{p}<0.001)$ (Tab. 2; Fig. 2ab) and abundance $(\mathrm{t}=2.74, \mathrm{p}<0.001)$ (Tab. 2; Fig. $2 b)$ when compared with the recent burn. The hydrologic condition with greater abundance was the dry year $(\mathrm{t}=4.15, \mathrm{p}<0.001)$ (Tab. 2; Fig. 2c), with 3,790 seedlings, being 2,467 in old burn and 1,323 in the recent burn. In the year of the flood, the abundance was lower with 3,195 
seedlings, 2,126 being in old burn and 1,069 in the recent burn. In regard to species richness, we also detected a significant difference between hydrologic conditions, with higher richness in the dry year $(t=5,296, p<0.001)$ (Tab. 2; Fig. 2d). The same way, the diversity also was affected by the hydrologic conditions, with higher diversity in the dry year $(\mathrm{t}=3.19, \mathrm{p}<0.01)$ (Tab 2; Fig. 3). We recorded 59 species in the dry year (44 in old burn and 46 in recent burn) and 53 in the year of the flood (44 in old burn and 40 in the recent burn).

\section{Influence of litter}

The abundance in samples with litter $(3,575$ seedlings) was similar to samples without litter $(3,620)$, without significant difference in either year of drought (Tab. 3; Fig. 4a) or flood (Tab. 3; Fig. 4b). In samples with litter, we found 37 species, compared with 24 without litter. There was no difference in richness in the dry year (Tab. 3; Fig. 4c). However, richness was higher in soil with litter in the year of the flood $(\mathrm{t}=2.193$; $\mathrm{p}=0.031$ ) (Tab. 3; Fig. 4d). We did not detect significant effects of litter on species diversity.
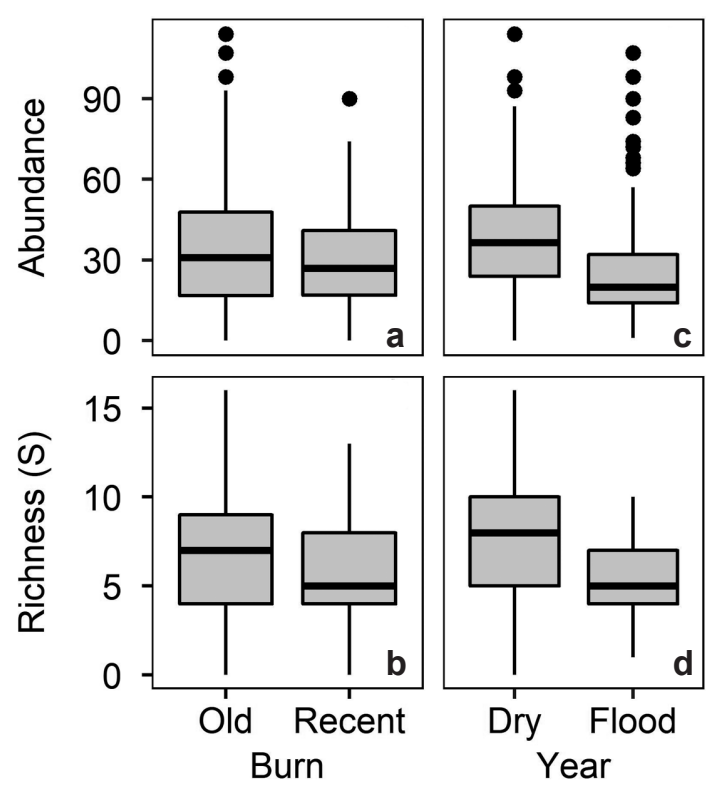

Figure 2 - Abundance (number of individuals) and species richness (S) comparing recent and old burn (a; b) and between dry and flood years (c; d), in the soil seed bank in riparian forest of the Paraguay River, Pantanal wetland, Brazil.

Table 2 - Generalized linear models to effect of flood and fire history on richness and abundance of the soil seed bank in riparian forest of the Paraguay River, Pantanal wetland, Brazil. Significant values $(p<0.05)$ in bold.

\begin{tabular}{lcccc}
\hline & Estimate & Std. Error & t value & Pr $(>|\mathbf{t}|)$ \\
\hline Abundance & & & & \\
(Intercept) & 3.83 & 0.08 & 49.21 & $<0.01$ \\
Dry year & 0.53 & 0.13 & $\mathbf{4 . 1 5}$ & $<\mathbf{0 . 0 1}$ \\
Old burn & 0.33 & 0.12 & $\mathbf{2 . 7 4}$ & $<\mathbf{0 . 0 1}$ \\
Flood year:recent burn & 0.36 & 0.19 & 1.95 & 0.05 \\
Richness & & & & \\
(Intercept) & 2.13 & 0.05 & 41.68 & $<0.01$ \\
Dry year & 0.43 & 0.08 & $\mathbf{5 . 3 0}$ & $<\mathbf{0 . 0 1}$ \\
Old burn & 0.24 & 0.08 & $\mathbf{3 . 1 5}$ & $<\mathbf{0 . 0 1}$ \\
Flood year:recent burn & 0.16 & 0.12 & 1.33 & 0.19 \\
Shannon diversity & & & & $<0.01$ \\
(Intercept) & 1.68 & 0.07 & 25.61 & $<\mathbf{0 . 0 1}$ \\
Dry year & -0.30 & 0.09 & $\mathbf{- 3 . 1 9}$ & 0.42 \\
Old burn & -0.08 & 0.09 & -0.81 & 0.72 \\
Flood year:recent fire & -0.05 & 0.13 & -0.35 & \\
\hline
\end{tabular}




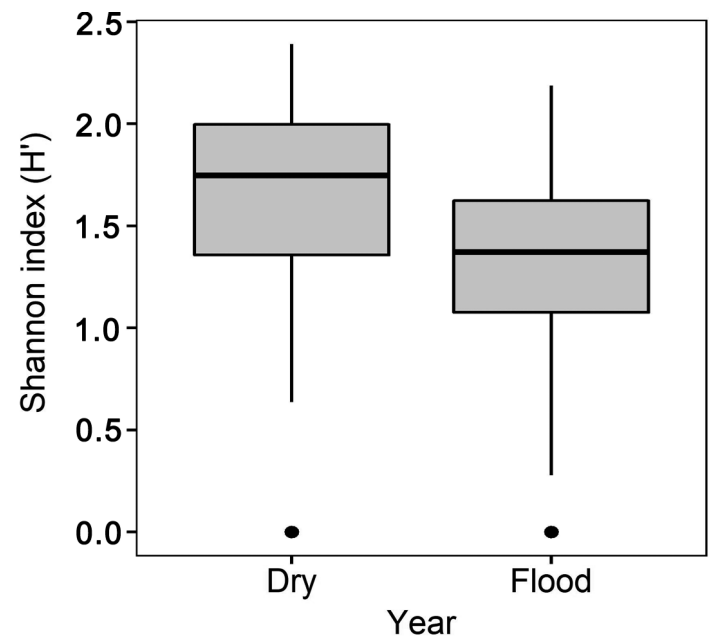

Figure 3 - Shannon diversity index (H') of soil seed bank samples between dry and flood years, in riparian forest of the Paraguay River, Pantanal wetland, Brazil.

\section{Discussion}

We observed that interannual differences in flood and different intervals in fire history can influence abundance, diversity and species richness of the riparian forest seed bank. These factors can promote or hinder germination, cause seed death and influence spatial distribution, richness and abundance of the seed bank. The seed bank of this riparian forest revealed a very high occurrence of herbaceous species. The predominance of herbs over woody species in the seed bank was also reported by other authors (e.g., Araújo et al. 2004; Siqueira et al. 2004). Such predominance is characteristic of temporally flooded areas (Leck \& Simpson 1994; Souza et al. 2016). A great part of the herbaceous species can occur in floodable environments due to their flood tolerance or flood escape strategies such as the annual life cycle, or total flood dependence (aquatic plants) (Souza et al. 2016). The last two traits are less frequent in woody species, which occur in these areas due to adaptations of flood tolerance (Parolin 2009). Herbaceous species present fast colonization (Daws et al. 2008), high seed productivity and high capacity of dispersal. Moreover, many herbs have high seed longevity, another reason why they become more abundant in the seed bank than woody species (Middleton 2003; Brock 2011).

The most abundant species were plants of the genera Cyperus, Ludwigia, Hymenachne, Borreria and Randia (Tab. 1). These genera also were the main ones in seed banks in a seasonal deciduous

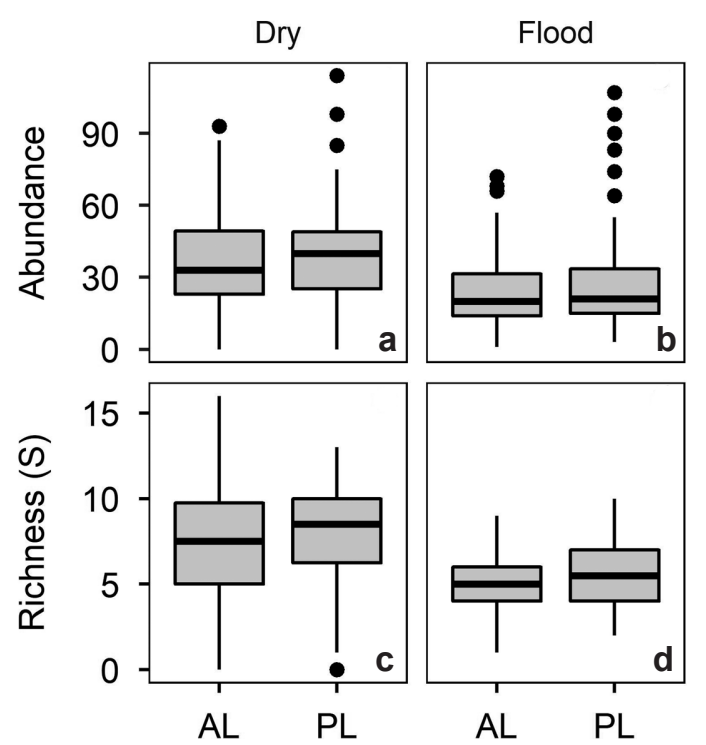

Figure 4-Abundance (number of individuals) and species richness (number of species) comparing soil samples with presence (PL) and absence of litter (AL) in dry (a; c) and flood years (b; d), in the soil seed bank in riparian forest of the Paraguay River, Pantanal wetland, Brazil.

riparian forest, Atlantic Forest and rice fields (Araújo et al. 2004; Mesquita et al. 2013), and some of these genera were also observed in seed bank in the Pantanal (Bao et al. 2014; Souza et al. 2016). Cyperus haspan was one of the most abundant species in the seed banks of seasonally flooded grasslands (Bao et al. 2014; Souza et al. 2016). In floodplains occur plant communities where the genera Panicum and Paspalum predominate, while on drier terraces the genera Acacia and Mimosa occur, as well as various pioneering families, such as Solanaceae and Asteraceae (Veloso et al. 1991). The presence of Asteraceae in the seed bank may be important for regeneration of local vegetation (Bechara et al. 2007). Representants of Asteraceae in the seed bank were Aspilia latissima Malme, Melanthera latifolia (Gardner) Cabrera and $M$. micrantha, all abundant pioneers in disturbed riparian vegetation (Pott \& Pott 1994). The high occurrence of Fabaceae is characteristic of fire prone-areas (Andrade \& Miranda 2014) since the fire has an important role in the overcoming of physical dormancy stimulating the germination of hard seeds of legumes, increasing their populations (Santana et al. 2010; Oliveira et al. 2014). In this regard, fire can increase seedling emergence and improve the regeneration of plant communities. 
Table 3 - Generalized linear models to effect of litter on richness and abundance of the soil seed bank in riparian forest of the Paraguay River, Pantanal wetland, Brazil. Significant values $(p<0.05)$ in bold.

\begin{tabular}{lcccc}
\hline & Estimate & Std. Error & t value & $\operatorname{Pr}(>|\mathbf{t}|)$ \\
\hline $\begin{array}{l}\text { Abundance Flood year } \\
\text { (Intercept) }\end{array}$ & 3.2229 & 0.112 & 28.787 & $<0.01$ \\
$\begin{array}{l}\text { Presence of litter } \\
\text { Abundance Dry year }\end{array}$ & 0.1817 & 0.1516 & 1.198 & 0.234 \\
(Intercept) & 3.60875 & 0.08414 & 42.89 & $<0.01$ \\
Presence of litter & 0.14028 & 0.11503 & 1.219 & 0.226 \\
Richness Flood year & & & & \\
(Intercept) & 1.57277 & 0.05629 & 27.939 & $<0.01$ \\
Presence of litter & 0.16769 & 0.07648 & $\mathbf{2 . 1 9 3}$ & $\mathbf{0 . 0 3 0 7}$ \\
Richness Dry year & & & & $<0.01$ \\
(Intercept) & 1.97685 & 0.06384 & 30.963 & 0.354 \\
Presence of litter & 0.08238 & 0.08849 & 0.931 & \\
Shannon diversity Flood year & & & & $<2 \mathrm{e}-16$ \\
(Intercept) & 1.26 & 0.06 & 20.76 & 0.14 \\
Presence of litter & 0.13 & 0.09 & 1.50 & $<2 \mathrm{e}-16$ \\
Shannon diversity Dry year & & & & 0.243 \\
(Intercept) & 1.58426 & 0.06987 & 22.673 & \\
Presence of litter & 0.11617 & 0.09882 & 1.176 & \\
\hline
\end{tabular}

Influence of post-fire periods and hydrologic conditions

There was no influence of fire and flood interaction on abundance, species richness and diversity of the seed bank, though, when analysed separately, either effect of fire or of the flood caused differences in total abundance of the seed bank. Nevertheless, these two variables can act together as a double filter (Arruda et al. 2016). In areas under deeper and/or longer flood, when fire eliminates the vegetation, the next flood hinders colonization, while in less flooded forests, fire opens gaps for regeneration, thereby favouring colonization (Oliveira et al. 2014). Thus, the seed bank can be the main regeneration mechanism. Under fire, the temperature rise on the surface and in the topsoil can affect either negatively the seed bank, by embryo death of seeds without tegument resistance (Hanley \& Lamont 2000). Some important herbaceous species in the region for being aquatic and terrestrial may not survive under fire effect (e.g., Bacopa australis, Ludwigia grandiflora, L. octovalvis and Rotala ramosior). On the other hand, in some cases, the fire can affect positively, by overcoming dormancy of species with hard seeds (Keeley et al. 2011), as in our study, for example, Paspalum repens, Mimosa adenocarpa and Sesbania exasperata.

Due to the environmental filter being able to influence in two ways, removing seeds from the bank by death or germination, this may be the reason why some local species common in the standing vegetation were more abundant in the areas of recent burn. Among these, we highlighted Cyperus haspan, Hyptis brevipes, Hymenachne amplexicaulis, Ceratopteris pteridoides, Randia armata and Cecropia pachystachya. It is possible that these species were not affected by the environmental filter since the presence of high abundance in the area with recent fire occurrence indicates that they are resistant and also their germination is less influenced by fire than the other species of this study. This favours them to maintain a larger number of seeds post-fire. Among the most abundant species (with more than 100 individuals), only Ludwigia decurrens had a considerable difference with greater abundance in the old burn (589) than in recent burn (140) 
areas. This indicates that the germination of $L$. decurrens can be affected by fire (germination or death), decreasing its abundance in the recent fire areas, probably because the seeds are small and lack hard testa.

Positive effects (dormancy overcoming) can be readily observed in tree species of the Cerrado with seeds with some degree of resistance to high temperatures of fire (Coutinho 1982) and drying when compared to gallery forest trees (Ribeiro \& Borghetti 2014). The pioneer shrub Sesbania virgata has a corky pod wherein the seeds could withstand mild fire. Although the seed bank gives certain post-fire resilience to the vegetation (Scott et al. 2010), large quantities of seeds can be killed during a wildfire, reducing their abundance in the soil (Blodgett et al. 2000), as we found in our study.

Seed abundance in areas of the recent burn was lower than the old burn. According to Whelan (1995), such difference can be related to a lower resistance of seeds under fire. Because of the Pantanal seasonality, with an aquatic phase and another terrestrial, there is the buildup of dry biomass, prone to wildfire (Junk et al. 1989). Herbs have short life cycles, so they can grow and set seed more readily after fire (Whelan 1995). This could explain the plant response to fire since sampling in areas of the old burn was made four years after the last fire, whereas in recent burn it was three months post-fire. Probably three years time was enough to replenish the seed bank by means of local seed rain or from adjacent areas (van der Valk \& Pederson 1989).

We found only two arboreal species, Triplaris americana and C. pachystachya. Cecropia spp. need light to germinate, thereby found in gaps, being indicators of secondary vegetation in forest zones (Parolin et al. 2002; Batista et al. 2008). In the riparian forest of the Paraguay River, $C$. pachystachya is an indicator of burned riverine woods (Oliveira et al. 2014), being dispersed by bats and birds (Pott \& Pott 1994). This tree lacks fire resistance mechanism, but it rapidly colonizes gaps left by fire (Godoi \& Takaki 2004), though it may resprout (Oliveira et al. 2014). Triplaris americana is anemochorous, thereby it easily reaches available gaps, which makes it abundant in riparian forests and floodable forest islets (Pott \& Pott 1994). With respect to the recorded shrubs, their diaspores can float, particularly the corky pod of $S$. virgata, while $R$. armata is ornitochorous (Pott \& Pott 1994).

Like fire, the flood can stimulate or inhibit germination of the seed bank. Our study revealed lower abundance, species richness and diversity of seeds in the soil in the year of flood compared with the drier year. Some studies indicate that continuous flood can inhibit the germination of most terrestrial and amphibious species, and only enhances germination of aquatic plants (Boedeltje et al. 2002). Furthermore, a prolonged flood can cause seed death (Baskin \& Baskin 2014), what could explain our results. Yet, other studies show that seasonal floods function as a trigger for germination, increasing post-flood recruitment from the seed bank and reducing abundance and species richness of seeds in the soil (Leck 1989; Jutila 2001; Hölzel \& Otte 2004; Souza et al. 2016). For some species, the nutrient buildup due to sedimentation and decomposition and, consequently, more nitrate and other factors, such as light requirement and anoxy, seem to be important mechanisms to overcome dormancy soon after water drawdown (Jutila 2001; Baskin $\&$ Baskin 2014). In this case, the lower abundance and species richness can reveal that the duration and intensity of flood were sufficient to affect the seed bank.

Either factor, flood or fire, are directly related with reduction of the seed rain, because of top kill of most species and diminished seed set, thereby reducing abundance in the seed bank. Nevertheless, in the Pantanal floodplain, the regeneration of the vegetation can improve by enhanced germination induced by flood, especially for annual herbs (Souza et al. 2016). It is evident that this riparian forest, prone to flood and fire, presents high abundance and species richness reflected by the seed bank. This indicates that there is a stock of seeds present in the soil capable to regenerate the vegetation, giving it resilience, independently on disturbance.

\section{Influence of litter}

In this study, the manual removal of litter in the flood year reduced species richness. Litter can represent a natural trap for seeds, especially in disturbed areas, accumulating more seeds than bare soil (Ruprecht \& Szabó 2012). In the Pantanal, during the flood occurs fast growth of aquatic plants, their aerial parts die post-flood and this organic layer builds upon the ground, providing substrate where seeds can increase their deposition (Middleton 2003). Furthermore, the litter can exert an important role in the protection of seeds against predation, but it can inhibit 
germination for restricting light entrance (Facelli \& Pickett 1991), allowing light dependent seeds (e.g., C. pachystachya) to remain for longer in the litter. In our study, litter removal in flood year excludes several species but the abundance is not altered.

Extreme seasonal events in the Pantanal are recurrent and predictable, and many species depend on these factors to become established. During a flood year, there is increased production of organic debris plus litter, but in a dry year, such fuel can produce intense wildfire. Although our results do not clarify if there is interaction between the factors, we found that fire and flood are explicative of the abundance and species richness of seedlings emerged from the seed bank of riparian forest in the Pantanal. In these ecological systems, where more than one extreme seasonal event shapes the plant community, the strategies of germination and establishment of the species are distinct, and the ecological traits of some species can indicate adaptative strategies.

The plant species found near water bodies (river) have adaptations to disturbances, such as dispersal by water and wind, for fast recovery post-fire (Dwire \& Kauffman 2003). However, we did not have a control treatment without fire, though such status would be hard to find in the Pantanal, except in river isles. The riparian forests of the Pantanal are considered to be shaped by and adapted to periodic wildfires (Arruda et al. 2016). Overall, we consider fire and flood as determinant factors in this riparian forest structure, since our results suggest that it presents high abundance and species richness of seeds, revealing that the seed bank contributes to the initial regeneration after extreme seasonal events. This is the first report on riparian forest seed bank in the Pantanal wetland. Therefore, these remote areas of difficult access should be further investigated, particularly the processes that influence the dynamics and maintenance of the plant species composition and diversity of riparian forests.

We conclude that fire and flood affect the seed bank richness, abundance and diversity, it can influence the seasonal regeneration and thus, the structure of the plant community. In areas with recent burn, there is less seed abundance because fire can act by killing plants, thereby reducing production of seeds, or benefiting them by overcoming dormancy (especially in legumes), decreasing seed in the soil. In addition, fire decreases the litter layer, and thus hinders to accumulate seeds, because they are more exposed to predation. Abundance and species richness is lower in the flood year than in the drier year. Flooding and fire can reduce the seed bank by death or by improving the germination of some species. The fire and flood interaction do not affect the abundance and species richness of the soil seed bank.

\section{Acknowledgements}

To the Brazilian agencies CNPq (Conselho Nacional de Pesquisas e Desenvolvimento Científico e Tecnológico e Inovação) and CAPES (Coordenação de Aperfeiçoamento de Pessoal de Nível Superior) for scholarships to the first four authors and research grant and Visiting Professor grant to A. Pott; Instituto Nacional de Áreas Úmidas (INAU/CNPq) for financial support; and Programa de Pós-Graduação em Biologia Vegetal of UFMS (Universidade Federal de Mato Grosso do Sul) for facilities.

\section{References}

Andrade LAZ \& Miranda HS (2014) The dynamics of the soil seed bank after a fire event in a woody savanna in central Brazil. Plant Ecology 215: 1199-209.

Araújo MS, Longhi SJ, Barros PL \& Brena D (2004) Caracterização da chuva de sementes, banco de sementes no solo e banco de plântulas em floresta estacional decidual ripária Cachoeira do Sul, RS, Brasil. Scientia Forestalis 66: 128-141.

Arruda WS, Oldeland J, Paranhos Filho AC, Pott A, Cunha NL, Ishii IH \& Damasceno-Junior GA (2016) Inundation and Fire Shape the Structure of Riparian Forests in the Pantanal, Brazil. PLoS One 11: 1-18.

Bao F, Pott A, Ferreira FA \& Arruda R (2014) Soil seed bank of floodable native and cultivated grassland in the Pantanal wetland: effects of flood gradient, season and species invasion. Brazilian Journal of Botany 37: 239-250.

Bao F, Leandro TD, Rocha M, Santos VS, Stefanello TH, Arruda R, Pott A \& Damasceno-Júnior GA (2017) Plant species diversity in a Neotropical wetland: patterns of similarity, effects of distance, and altitude. Anais da Academia Brasileira de Ciências, 90: 85-97.

Bao F, Elsey-Quirk T, Assis MA, Arruda R \& Pott A (2018)Seasonal flooding, topography, and organic debris interact to influence the emergence and distribution of seedlings in a tropical grassland. Biotropica 50: 616-624.

Baskin CC \& Baskin JM (2014) Seeds: Ecology, Biogeography, and Evolution of Dormancy and 
Germination. $2^{\mathrm{a}}$ ed. Academic Press, San Diego. $1600 p$.

Batista CU, Bianchini E, Medri M \& Pimenta J (2008) Tolerância à inundação de Cecropia pachystachya Trec. (Cecropiaceae): aspectos ecofisiológicos e morfoanatômicos. Acta Botanica Brasilica 2: 91-98.

Bechara F, Campos Filho E, Barretto K, Gabriel V, Antunes A\& Reis A(2007) Unidades demonstrativas de restauração ecológica através de técnicas nucleadoras de biodiversidade. Revista Brasileira de Biociências 5: 9-11.

Blodgett H, Hart G \& Stanislaw M (2000) Annual burning decreases seed density in the upper soil layers of the seed bank. Tillers 2: 31-38.

Boedeltje G, ter Heerdt GNJ \& Bakker JP (2002) Applying the seedling-emergence method under water logged conditions to detect the seed bank of aquatic plants in submerged sediments. Aquatatic Botany 72: 121-128.

Brasil (1979) Estudos de desenvolvimento integrado da Bacia do Alto Paraguai. Relatório de $1^{\mathrm{a}}$ fase. EDIBAP. Ministério do Interior, Superintendência do Desenvolvimento da Região Centro-Oeste (SUDECO), Brasília. t.2, 235p.

Brock MA (2011) Persistence of seed banks in Australian temporary wetlands. Freshwater Biology 56: 1312 1327.

Brock MA \& Rogers KH (1998) The regeneration potential of the seed bank of an ephemeral floodplain in South Africa. Aquatic Botany 61: 123-135.

Brock MA, Nielsen DL, Shiel RJ, Green JD \& Langley JD (2003) Drought and aquatic community resilience: the role of eggs and seeds in sediments of temporary wetlands. Freshwater Biology 48: 1207-1218.

Coutinho LM (1982). Ecological Effects of fire in Brasilian cerrado P 273-291. In: Huntley B \& Walker B (eds.) Ecology of Tropical Savannas. Springer-Verlag, Berlin. Pp: 273-291.

Damasceno-Junior GA, Semir J, Santos FAM \& LeitãoFilho F (2004) Tree mortality in a riparian forest at Rio Paraguai, Pantanal, Brazil, after an extreme flooding. Acta Botanica Brasilica 18: 839-846.

Daws M, Pearson TR, Burslem DFR, Mullins C \& Dalling J (2008) Germination responses to water potential in neotropical pioneers suggest larger seeded species take more risks. Annals of Botany 12: 945-951.

Dwire K \& Kauffman J (2003) Fire and riparian ecosystems in landscapes of the western USA. Forest Ecology and Management 178: 61-74.

Facelli J \& Pickett ST (1991) Plant litter: its dynamics and effects on plant community structure. The Botanical Review 57: 1-32.

Fernandes FA, Fernandes AHBM, Soares MTS, Pellegrin LA \& Lima IBT (2007) Atualização do Mapa de Solos da Planície Pantaneira para o Sistema Brasileiro de Classificação de Solos. EMBRAPA, Comunicado Técnico 61: 1-6.

Godoi S \& Takaki M (2004) Effects of light and temperature on seed germination in Cecropia hololeuca Miq. (Cecropiaceae). Brazilian Archives of Biology and Technology 47: 185-191.

Hamilton SK, Sippel SJ \& Melack JM (1996) Inundation patternes in Pantanal wetland of South America determined from passive microwave remote sensing. Archiv fur Hydrobiologie 137: 1-23.

Hanley ME \& Lamont BB (2000) Heat pre-treatment and the germination of soil- and canopy-stored seeds of south-western australian species. Acta Oecologica 21: 315-321.

Hölzel N \& Otte A (2004) Inter-annual variation in the soil seed bank of flood-meadows over two years with different flooding patterns. Plant Ecology 174: 279-291.

Junk WJ, Bayley PB \& Sparks RE (1989) The flood-pulse concept in river-floodplain systems. In: Dodge DP (ed.) Proceedings of the International Large River Symposium. Canadian Journal of Fisheries and Aquatic Sciences 106: 110-127.

Jutila HM (2001) Effect of flooding and draw-down disturbance on germination from a seashore meadow seed bank. Journal of Vegetation Science 12: 729-738.

Keeley JE, Pausas JG, Rundel PW, Bond WJ \& Bradstock RA (2011) Fire as an evolutionary pressure shaping plant traits. Trends in Plant Science 16: 406-411.

Keith DA \& Bradstock RA (1994) Fire and competition in Australian heath : a conceptual model and field investigations. Journal of Vegetation Science 5: 347-354.

Leck MA (1989) Wetland Seed Banks. In: Leck MA, Parker VT, Simpson RL (eds.) Ecology of soil seed banks. Academic Press, San Diego. Pp 283-305

Leck MA \& Simpson RL (1994) Tidal freshwater wetland zonation: seed and seedling dynamics. Aquatic Botany 47: 61-75.

Mesquita MLR, Andrade LA \& Pereira WE (2013) Floristic diversity of the soil weed seed bank in a rice-growing area of Brazil: In situ and ex situ evaluation. Acta Botanica Brasilica 27: 465-471.

Middleton BA (2003) Soil seed banks and the potential restoration of forested wetlands after farming. Journal of Applied Ecology 40: 1025-1034.

Moreira B \& Pausas JG (2012) Tanned or Burned: The role of fire in shaping physical seed dormancy. PLoS One 7: 1-8.

Oksanen J, Blanchet FG, Friendly M, Kindt R, Legendre P, McGlinn D, Minchin PR, O'Hara RB, Simpson GL, Solymos P, Stevens MHH, Szoecs E \& Helene W (2017) Vegan: Community Ecology Package. 
R package version 2.5-2. Available at $<$ https:// CRAN.R-project.org/package $=$ vegan $>$. Access on 21 October 2017.

Oliveira MT, Damasceno-Junior GA, Pott A, Paranhos Filho AC, Suarez YR \& Parolin P (2014) Regeneration of riparian forests of the Brazilian Pantanal under flood and fire influence. Forest Ecology And Management 331: 256-263.

Parolin P (2009) Submerged in darkness: adaptations to prolonged submergence by woody species of the Amazonian floodplains. Annals of Botany 103: 359-376.

Parolin P, Oliveira A, Piedade MT, Wittmann F \& Junk W (2002) Pioneer trees in Amazonian floodplains: three key species from monospecifc stands in different habitats. Folia Geobotanica 37: 225-238.

Pott A \& Pott VJ (1994) Plantas do Pantanal. EMBRAPACPAP, Corumbá. 320p.

Pott VJ \& Pott A (2000) Plantas aquáticas do Pantanal. EMBRAPA, Brasilia, DF. 404p.

R Core Team (2017) R: a language and environment for statistical computing. R Foundation for Statistical Computing, Vienna, Austria. Available at $<$ https:// www.R-project.org/> Access on 21 October 2017.

Ribeiro LC \& Borghetti F (2014) Comparative effects of desiccation, heat shock and high temperatures on seed germination of savanna and forest tree species. Austral Ecology 39: 267-278.

Ruprecht E \& Szabó A (2012) Grass litter is a natural seed trap in long-term undisturbed grassland. Jounal of Vegetaton Science 23: 495-504.

Santana V, Bradstock R, Ooi MK, Denham A, Auld T \& Baeza MJ (2010) Effects of soil temperature regimes after fire on seed dormancy and germination in six Australian Fabaceae species. Australian Journal of
Botany 58: 539-545.

Santana VM, Baeza MJ \& Blanes MC (2013) Clarifying the role of fire heat and daily temperature fluctuations as germination cues for Mediterranean Basin obligate seeders. Annals of Botany 111: 127-134.

Scott K, Setterfield S, Douglas M \& Andersen A (2010) Soil seed banks confer resilience to savanna grasslayer plants during seasonal disturbance. Acta Oecologica 36: 202-210.

Siqueira L, Matos M, Matos DM, Portela RC, Braz MI \& Lima L (2004) Using the variances of microclimate variables to determine edge effects in small forest fragments of Atlantic Rain Forest, Southeastern Brazil. Ecotropica 10: 59-64.

Soriano BMA (1997) Caracterização climática de Corumbá-MS. Boletim de Pesquisa 11. EMBRAPACPAP, Corumbá. 25p.

Souza EB, Ferreira FA \& Pott A (2016) Effects of flooding and its temporal variation on seedling recruitment from the soil seed bank of a Neotropical floodplain. Acta Botanica Brasilica 30: 560-568.

van der Valk AG \& Pederson RL (1989) Seed bank and managenent and restoration of natural vegetation $P$ 329-346. In: Leck MA, Parker VT \& Simpson RL (eds.) Ecology of soil seed banks. Academic Press, San Diego. Pp 283-305.

Veloso HP, Rangel Filho ALR \& Lima JCA (1991) Classificação da vegetação brasileira, adaptada a um sistema universal. Ministério da Economia, Brasília, DF. 124p.

Whelan RJ (1995) The ecology of fire. Cambridge University Press, Cambridge. 360p.

Zuur AF, Ieno EN, Walker NJ, Saveliev AA \& Smith GM (2009) Mixed effects models and extensions in ecology with R. Springer, New York. 600p. 